Please do not remove this page

RMIT

UNIVERSITY

\title{
The Impact of Multilingualism on Reporting Domestic Violence in Mozambique
}

Heydon, Georgina; Mabasso, Eliseu

https://researchrepository.rmit.edu.au/esploro/outputs/9921858838401341/filesAndLinks?institution=61RMIT_INST\&index=null

Heydon, G., \& Mabasso, E. (2018). The Impact of Multilingualism on Reporting Domestic Violence in Mozambique. Language Matters, 49(1), 84-106. https://doi.org/10.1080/10228195.2018.1444081

Document Version: Accepted Manuscript

Published Version: https://doi.org/10.1080/10228195.2018.1444081

Repository homepage: https://researchrepository.rmit.edu.au

(C) Unisa Press 2018

Downloaded On 2023/04/27 01:00:57 +1000

Please do not remove this page 
Thank you for downloading this document from the RMIT Research Repository.

The RMIT Research Repository is an open access database showcasing the research outputs of RMIT University researchers.

RMIT Research Repository: http://researchbank.rmit.edu.au/

\section{Citation:}

Heydon, G and Mabasso, E 2018, 'The Impact of Multilingualism on Reporting Domestic Violence in Mozambique', Language Matters, vol. 49, no. 1, pp. 84-106.

See this record in the RMIT Research Repository at:

https://researchbank.rmit.edu.au/view/rmit:48955

Version: Accepted Manuscript

Copyright Statement:

(C) Unisa Press 2018

\section{Link to Published Version:}

https://dx.doi.org/10.1080/10228195.2018.1444081 


\title{
The Impact of Multilingualism on Reporting Domestic Violence in Mozambique
}

\author{
Georgina Heydon
}

https://orcid.org/0000-0002-0521-2227

RMIT University, Social and Global Studies Centre, Australia

georgina.heydon@rmit.edu.au

\section{Eliseu Mabasso}

Universidade Eduardo Mondlane, Faculty of Arts and Social Science, Mozambique eliseumabasso@gmail.com

\begin{abstract}
This article examines the linguistic environment in which police and justice agencies conduct interviews in domestic violence cases in Maputo, Mozambique. In Maputo, most people speak one or more African languages and many do not speak the official language, Portuguese, fluently. Moreover, a complex justice environment in Maputo incorporates customary law such as community-based mediation. This article examines justice and civil society stakeholder attitudes towards the role of language in the justice system. Interviews with staff from ten agencies indicate that stakeholders recognise the positive value for victim-survivors of domestic violence to tell their story in their own language. However, stakeholder agencies sometimes act as "linguistic gate-keepers" and the authors conclude that a suitable first step in improving the state's response to domestic violence is the development of tools to support agency staff at all levels in explaining legal terminology and processes in simple Portuguese, or local language translations.
\end{abstract}

Keywords: police interviewing; language diversity; legal pluralism; violence against women; access to justice; forensic linguistics

\section{Introduction}

\subsection{Language and the Justice Gap in Domestic Violence}

This article explores the complex role of language as a barrier to justice for women reporting domestic violence (DV) in Maputo, Mozambique. It is well established that lack of proficiency in a state's official language can prevent access to justice (Gibbons 2003, 21121). In most studies to date, however, there is at least a recognition by the main actors within the justice sector that multilingual services are required, even though the actual services provided are generally inadequate to meet the needs of the culturally and linguistically diverse communities who rely upon them (Hertog and Van Gucht 2008). The present study, 
by contrast, took place in a setting where linguistic diversity is a fact of everyday life, and yet the need for multilingual services in justice agencies seems contested.

Mabasso (2013) documents the potential for miscarriages of justice to occur in police interviews in Maputo due to the linguistic diversity of suspects and their lack of proficiency in Portuguese, the official language of Mozambique. The present research explores languagerelated obstacles to justice for women making reports about DV to a range of justice agencies in Maputo. In particular, this article considers the linguistic obstacles as contributing to the justice gap that exists in the legal response to DV cases in countries around the world. This parallels the justice gap in responses to gendered violence more generally (Brown 2011) and can be broadly understood as a very low rate of reporting combined with a high rate of case attrition such that very few cases are pursued through the courts or result in a conviction at trial (Heydon and Powell 2016). The causes of attrition are varied but include case withdrawal by the victim-survivor as well as decisions by justice agencies not to investigate or prosecute certain cases. Social pressure on women not to admit to violence perpetrated by their husbands, or victim-survivors not being believed by police are factors that are commonly understood to discourage women from initiating the reporting process. When women do report DV to police, inadequacies in the interviewing and information-gathering procedure are often cited as reasons why police prosecutors fail to secure a conviction, if the case proceeds to trial at all. Although improvements are being made to police attitudes and to the methods used to gather evidence, there has been less emphasis placed on exploring language as a common variable that cuts across each of these aspects of the justice gap. This is despite a number of studies which address discourse of courtroom trials (Cotterill 2003), and specifically rape and DV trials (Matoesian 1993, Ehrlich 2001, Trinch 2003).

The justice gap for women reporting DV in Maputo, Mozambique is exponentially widened by the complex array of factors that form an almost impenetrable wall between victimsurvivors and a safe domestic life, free from fear of violence. At every stage of the reporting process, language and in particular proficiency in the official language, Portuguese, is a crucial element influencing a woman's choices and generally narrowing her available options. The interaction between colonial languages and indigenous languages has been well documented in research that seeks to address the "language question" in Africa (Kamwangamalu 2016). It is in the context of a failure of language policies in Africa (Kamwangamalu 2016, 26) that women reporting DV in Maputo encounter specific 
problems, in addition to the barrier of a hostile courtroom environment for rape and DV victims (Matoesian 1993, Ehrlich 2001, Trinch 2003).

The remainder of this introduction presents in some detail the historical, political and legal context to the Mozambican response to DV. Given the impact of civil conflict and a culture of violence on women and girls particularly, a greater than usual space is devoted to setting out the aforementioned historical factors that continue to influence public policy and daily life in Mozambique. Moreover, there has been scant research into the impact of linguistic diversity on the functioning of the justice system in Mozambique, and therefore the authors intend that by presenting the relevant context to the issue here, it might serve as a useful reference for future scholarship in the region.

Following the contextual and background information presented in the remained of section 1, section 2 presents the method of the study. In section 3 the main results are divided into three parts: the perceptions of linguistic diversity by the participants; the response to linguistic diversity and the resources available to participants and their organisations to manage linguistic diversity in their working environment. A discussion of the results is presented in section 4, and section 5 presents the concluding remarks and recommendations for future research.

\subsection{The Justice Environment in Mozambique}

The current government in Mozambique has its roots in the war of independence against Portuguese colonial rule, which ended when the country achieved independence from Portugal in 1975. The subsequent civil war, which lasted from 1976 to 1992, had a devastating impact on the Mozambican people and has left the country with high levels of poverty, poor infrastructure, and a poorly resourced government. Mozambique's legal system can best be described as official legal pluralism, with formal recognition of customary law, a constitution, and a written civil law code based on the colonial Portuguese legal regime, all of which operate within a socialist framework (Pimentel 2011).

Pimentel (2011) finds that in Mozambique "access to justice is a major rule-of-law deficiency [as] in many post-colonial African states." The Open Society Initiative report on the rule of law in Mozambique further describes the situation as follows: 
On balance, despite its reform efforts, the state is unable to guarantee access to justice for its citizens, particularly those living in remote areas. The reality for most Mozambicans is that the judicial courts are inaccessible, blocked by a range of obstacles including financial constraints and their physical location. As a result, many citizens continue to rely on alternative mechanisms of dispute resolution, including community courts and traditional or other local leaders. (Open Society Initiative for Southern Africa 2006, 121)

In a study of violence against women that surveyed both police and community respondents, Saini, Cumbe and Levy (2013) found that a lack of transparency in the legal process is a factor that discourages the reporting of sexual assault. This was exemplified by respondents who cited a tendency of the courts to transmute prison terms into fines, and the high level of influence that wealth or social status could have in court outcomes. Added to this, the study found that girls were fearful of the stigma and discrimination attached to reporting sexual assault which could ruin their marriage prospects (Saini, Cumbe and Levy 2013). One report suggests that women who make a formal complaint face hostility from the relatives of their husband or partner, which can be translated into threats and physical aggression, isolation or denial of access to resources (Arthur and Mejia 2007). There is often a rise in violence by the aggressor subsequent to police intervention (Arthur and Mejia 2007).

An important factor relevant to the present study is the impact of language on access to justice in each of the different legal systems. Whereas the institutions of the formal legal system (police and prosecutors, for instance) will conduct their inquiries in the official language-Portuguese-local community leaders or community police representatives can usually conduct their interactions with the victim and her family in a local Mozambican language. This issue is explored in more detail below.

\subsection{The Prevalence of Domestic Violence in Maputo}

The 2012 Demographic and Health Survey (DHS) reported that one in three Mozambican women had experienced violence at least once since the age of 15 . The same study found that " $12 \%$ of women reported being forced to have sex at some point in their lifetime" (Instituto Nacional de Estatística, Ministerio da Saude, M, Moçambique, and MEASURE DHS/ICF International 2012, 245). In 59\% of these cases of sexual assault, the women did not seek any assistance or report the sexual violence to anyone (p. 273).

A study of victims of Intimate Partner Violence (IPV) conducted in emergency departments across three health care sites in Maputo in 2007 found that victims of IPV $(n=92,63 \%$ 
women) were less educated (primary school or less) (84\%) compared to national averages; were likely to be students or have no formal career $(68.5 \%)$; and to be of Catholic or Christian religion (75\%) (Jetha et al. 2011). In the study population, 94\% were living below the poverty line (Jetha et al. 2011).

Another more extensive study conducted in Maputo, by Zacarias et al. (2012), confirmed that most women victimised in the context of IPV had limited financial resources, although this study also suggested in contrast that higher education levels - and divergence from normative gender roles - were associated with vulnerability to psychological violence.

\subsection{The Response to Domestic Violence}

In 1998 a coalition came together for the All Against Violence campaign, which involved direct support for victims, public education and counselling, training and education on human rights and gender inequalities, and research on violence against women (Loforte 2009). This placed pressure on the government to act and to comply with CEDAW (the United Nations' Convention on the Elimination of All Forms of Discrimination Against Women) and specifically the Optional Protocol to CEDAW, which was ratified by Mozambique in 2008 (Loforte 2009).

In 2009, following these campaigns and the ratification of CEDAW, the Mozambican parliament passed a specific DV law, which prohibits physical, financial, emotional, and sexual violence against women, including marital rape. ${ }^{1}$ In 2012, the Mozambican government implemented a national plan to address violence against women across five provinces. This included a television and radio campaign led by the Ministry of Women that informed women of their rights under the legislation (www.genderindex.org accessed March $25^{\text {th }} 2018$ ).

As part of efforts by the Polícia da República de Moçambique (PRM-Mozambique Police Force) to improve responses to victims, particularly women and children, special consultation rooms (gabinetes) have been set up in some police stations. The establishment of the Gabinetes de Atendimento a Mulher e Criança Vitimas de Violencia Doméstica ('Offices to Assist Women and Child Victims of Domestic Violence') in the early 2000s represents a significant national initiative for mounting a response to gender-based violence (Saini,

\footnotetext{
${ }^{1}$ Law on Domestic Violence Perpetrated Against Women Act, enacted 29 September 2009.
} 
Cumbe and Levy 2013). Overseen by the Ministry of the Interior and usually staffed by female police officers, gabinetes are private areas for survivors to report cases and are located either within police stations or in standalone buildings called "model cabinets" (Pathfinder International 2015). By the end of 2005, 96 police stations had been fitted with these special consultation rooms (Government of Mozambique 2005, 131; Open Society Initiative for Southern Africa 2006).

While the gabinetes represent to many a progressive step, in practice they have been unable to offer survivors a comprehensive package of services. For example, police services are available but offer limited legal assistance, and have no connection to the various health services a survivor may require. This subjects survivors to the trauma of reliving their experience as they repeat their case at multiple service entry points, and leaves them without access to essential treatment, care, and support (Pathfinder International 2015). These factors, combined with the lack of transparency in the legal system identified by Saini, Cumbe, and Levy (2013), are perhaps the reason why the US Department of State's 2012 human rights report on Mozambique reports that "many families still chose to settle cases of sexual violence through community courts or through private financial remuneration rather than through the judicial system" (US Department of State 2012, 18).

\subsection{Language and the Law in Mozambique}

As set out in article 10 of the 2004 Constitution (see Appendix A), Portuguese is Mozambique's official language, and is therefore the language of the legal system. However, according to official statistics only 40 per cent of the population are at least partly fluent in Portuguese, and in rural populations, the level of Portuguese proficiency drops to 25 per cent (Mabasso 2013). Only 7 per cent of the population considered Portuguese their mother tongue and the vast majority of Mozambicans have as their native language one of several Bantu languages. According to Lopes (1998) Emakhwa, which is spoken by an estimated $27 \%$ of Mozambicans, and Shangaan (11.3\%) are the two most spoken Bantu languages. The less common languages include Cisena (7.5\%), Elomwe (7\%), Echuwabo (5.1\%), other Mozambican languages (30.1\%), and foreign languages (4\%), according to the 1997 census. $^{2}$ Thus Mozambique is a country of high linguistic diversity according to the definition

\footnotetext{
${ }^{2}$ It should be noted that in most African countries pure language censuses are rare and the most up to date information on the percentage of speakers of other Bantu languages of Mozambique is from the 1997 census.
} 
provided by Robinson (1993, 52-55), that "no more than fifty per cent of the population speak the same language."

Article 98 of the Criminal Procedure Code requires courts to appoint an interpreter for nonPortuguese speaking defendants. While some attempt is made by courts to provide interpreters, there are few professionally trained interpreters available and very often, courts will use a bilingual member of staff, or even a member of the community instead of a trained interpreter. As we confirmed in our research, it is also the practice of judges in district courts to conduct parts of the proceedings in the local language of participants, or act as an interpreter for other members of the court if they (the judges) speak the local language themselves (Open Society Initiative for Southern Africa 2006, 111). As a result, most nonPortuguese speaking victims are not in fact provided with an independent interpreter. Victims appearing in court or being interviewed in relation to a case are instead reliant on the judges, their legal representative or other court officials to provide them with partial interpretations as they see fit. This response to the language needs of victims by justice institutions is inadequate and does not meet the requirements of the Criminal Procedure Code Article 98. The impact of this language services failure will be explored throughout this article.

For victims of DV, the language barrier is likely to be even greater than for the general population. For $93 \%$ of the population Portuguese is a second language. It is acquired through education, and maintained though ongoing workplace engagement. Given that a great many women experiencing DV are living below the poverty line, are not in paid work and have only a primary school education, they are less likely than the general population to speak Portuguese with sufficient fluency to conduct legal negotiations or provide a detailed and accurate account of their experiences.

Within the political, cultural and legal environment described above, it appears that language is indeed an inhibiting factor in women's capacity to access justice following an experience of DV. Language policy and practices are important aspects of DV reporting that require further examination and explication.

Given that this is the first study to address the language-based iniquities of the Mozambican justice system that routinely disadvantage women reporting DV, we first sought to ascertain how legal professionals and social support workers understand the language challenges for 
non-Portuguese speakers reporting DV in Mozambique. This article provides an opportunity to represent the direct experiences of legal and social service providers in responding to linguistic diversity amongst help-seeking victim-survivors of DV in Maputo. The service providers' attitudes and beliefs about language are interpreted against the backdrop of the sociocultural factors described above and provide some insight into the specific challenges faced by the frontline responders and their opinions about resources or tools that could bridge the language gap.

\section{Method}

The interview data represented in this article were collected as part of a broader programme of research which is concerned with the role of forensic interviewing in police investigations in Maputo. While this article is based on qualitative data drawn from stakeholder interviews, it builds on empirical research analysing the transcripts of recorded police interviews with suspects in Maputo (Mabasso 2013). That research demonstrated that Portuguese language proficiency was an important and relevant factor in the suspects' capacity to provide an account of themselves to police and to report accurately their version of events.

In the present study, qualitative semi-structured interviews were conducted with key stakeholders in ten government and non-government organisations in the DV sector (see below). Over a period of two weeks in March 2016, the research team visited justice and social support organisations which were selected in part on the basis of an earlier field study in 2014, and in part through suggestions from existing participants (i.e. snowballing).

The team conducted interviews with staff across a range of roles, from frontline legal advisors and counsellors, to directors and senior government officials.

\subsection{Data Collection}

Interviews were conducted by an English-speaking interviewer (Heydon) with the assistance of a Portuguese-English professional interpreter. A second researcher fluent in Portuguese and English (Mabasso) provided a supporting commentary on aspects of the participants' contributions, clarifying cultural or political points and assisting the professional interpreter with technical terms as required. Interviews were recorded electronically whenever possible and the researchers took extensive field notes to support the analysis of data. 
Interview schedules (see Appendix B) were devised for the interviews with staff in different agencies in order to support our research goals. The interview questions sought to elucidate the intersection of customary law and language diversity in the reporting of DV by women in Maputo. An important supporting theme in our interviews was therefore the role of language in facilitating or restricting access to justice for women reporting DV. This article reports on the findings relating to that theme in the interview data although the interviews as a whole included several other themes concerning customary law, trace evidence, training and professional development. These will be the focus of future publications.

\subsection{Data}

Understanding the context of an organisation's work was an important aspect of the interview. A brief outline is provided below of the context within which each participating agency operates and how each agency takes reports from victims of DV.

Four official government justice agencies participated in the study: the Prosecutor-General's Department (PGR), the Judicial Training College, the Special Police Unit for Gabinetes de Atendimento a Mulher e Criança Vitimas de Violencia Doméstica ('Offices to Assist Women and Child Victims of Domestic Violence') and Academia de Ciências Policiais (ACIPOL), the police training college.

The prosecutors in the PGR investigate crimes directly, as is usual in civil law systems, and have representatives stationed within police departments, as well as in their own offices where civilians can report crimes and request an investigation. As a result, the regional and urban offices of the PGR are a potential point of contact for women reporting DV.

The Judicial Training College plays an important role in training judicial officers who will investigate crimes under the inquisitorial model in their courts. The Judicial Training College was our main point of contact with the judiciary in this research, and an important source of information about practices and attitudes of judicial officers in Maputo. State judges generally preside over cases with two community judges, whose function and background loosely resemble those of jurors in an adversarial courtroom.

The Special Police Unit or gabinete in Maputo, described in more detail in the introduction above, is staffed by 30 officers (men and women) specially trained in human rights. Although 
officially they undertake interviews with victims, witnesses and suspects, and collate such interview statements with medical reports and other evidence for the prosecution, it was clear that the officers also mediate cases between parties, which we observed during our several visits to the unit.

ACIPOL was established in Maputo in an effort to improve recruitment and provide training to police as well as to professionalise the force in response to human rights abuse allegations (Open Society Initiative for Southern Africa 2006). The interviews at ACIPOL provided us with access to the views of training officers who have in the past conducted investigations as active police officers.

The Community Police unit represents a bridge between government and non-government agencies, and, as described in section 1.2 above, was established to mediate the relationship between citizens and the formal justice system. In rural areas where police presence is limited, these officers assume the role of community leaders and have specific powers to investigate complaints, within clearly articulated (though not always observed) limits. ${ }^{3}$ With the criminalisation of DV in 2009, this changed their role in marital disputes especially. Whereas it was accepted practice for Community Police officers to mediate DV disputes and usually counsel the couple to cease fighting and live together peaceably, now they are required to pass on a report of such cases to police or the PGR. It became clear in our fieldwork, however, that it was not uncommon for Community Police officers to assess the DV incident as "non-violent" or non-criminal in order to avoid sending the case on to the courts. They saw this as providing a service to their community and saving people the expense of a trial, which is no doubt a legitimate concern. There was also a strong view that marriages were to be preserved, as they provide the only source of financial support for most women and their children. Again, this is undoubtedly true, although legally women are entitled to receive maintenance payments from their ex-husbands.

Muleide, Associação Moçambicana das Mulheres de Carreira Jurídica (AMMCJ), Liga Mocambicana dos Direitos Humanos (the Liga) and Forum Mulher are all civil society organisations that provide legal advice and counselling services to women in Maputo. All of these organisations engage in advocacy and education campaigns in addition to their frontline

\footnotetext{
${ }^{3}$ The term "leader" is also used to refer to a less formal role played by community authorities in urban areas. In our research, the interviewees consistently emphasised the importance of engaging with all of these authority figures, whether they were regarded as community leaders, block leaders or community police officers.
} 
support services. They are typically funded by international donor agencies and staffed by well-educated men and women operating within an international human rights framework.

The Universidade Eduardo Mondlane's (UEM) Centre for Human Rights is also externally funded, and while it is situated within the Law Faculty of the university, it is not integrated with the faculty's teaching programmes. The centre provides human rights education and training programmes to government agencies and departmental officials, which has become especially important as Mozambique participates more actively in international conventions and fora where human rights form a foundational structure for policy-making and agreements.

\section{Results}

The interview data were analysed in relation to three specific themes relevant to this research:

- the stakeholders' perceptions of linguistic diversity and Portuguese proficiency amongst their clientele; ${ }^{4}$

- the strategies used by stakeholders to respond to the linguistic diversity and level of Portuguese proficiency amongst their clientele; and

- the resources stakeholders have available to them to disseminate information to their clientele and the public at large.

\subsection{Perceptions of Linguistic Diversity}

As expected, all of the stakeholders interviewed in each of the ten agencies involved in the study reported that the overwhelming majority of their clientele spoke a local Bantu language as their mother tongue. Most victims are speakers of either Shangaan or Ronga or even of a mixture of both as these are the two sister languages that are particularly widely spoken in Maputo. As one of our participants at an NGO reported, "we always try to make ourselves understood when we share the same local language but this can become problematic when the language spoken by the victim is not shared by the paralegals in charge." 5

\footnotetext{
${ }^{4}$ We use the term "clientele" to refer to actual users of a DV service, such as victim-survivors, suspects, relatives and friends of the same, and also potential users in the general public.

${ }^{5}$ This information was shared by a paralegal at the Liga.
} 
Very rarely did any of the stakeholders mention clientele with strong Portuguese proficiency; however, agencies such as the Liga recognised that their clientele can come from any background, and some are indeed members of the educated, middle class, which would imply that they have good Portuguese fluency. Overall, however, our interview data clearly indicate that the majority of the clientele served by these ten justice and legal support agencies were perceived to have insufficient proficiency in Portuguese to be understood or to navigate the legal system.

\subsection{Responses to Linguistic Diversity}

The civil society organisations responded to this linguistic diversity amongst their clientele by utilising knowledge of local languages amongst their staff. Some, such as the Forum Mulher, required that their counsellors and paralegals have proficiency in a local language, but it was apparently more difficult to enforce this requirement with staff lawyers. Staff at the civil society organisations provide assistance with the Portuguese legal terminology for their clients, and for those cases that go to court, language assistance is provided by paralegals and some lawyers. Most of the staff described experiences where they had to interview clients whose language they did not speak. In those situations, the staff would improvise by either communicating some basic information using a mixture of Portuguese and Shangaan, or trying to find someone in the organisation to act as an ad hoc interpreter. Sometimes staff would draw on multilingual or graphic information resources (see below) to explain the legal process to clients. None of the agencies claimed to be able to provide a complete service across all the languages that their clients used.

The government agencies involved in this study varied somewhat in their reported use of strategies to manage language diversity. Several staff members at the PGR reported learning a local language, Shangaan, when working outside the capital, because they said they could not have conducted investigations without it. In interviews with clients, they used their knowledge of Shangaan to explain legal terms and procedures and they especially noted that when the victim was able to give her version of events in her own language, she found the process less disturbing and was better able to recount her story of abuse to the prosecutor.

Apart from taking the initiative to learn the local language, PRG officers make other ad hoc provisions to allow women to express themselves in their mother tongue. For example, one option is for prosecutors to seek a reliable colleague who speaks a victim's first language to 
interview her. Another option in court was to use the community judges (similar to a jury of peers - see above) as impromptu interpreters.

The Commander at the Special Police Unit explained that before the police interview, a lawyer would explain the legal process to the victim (and suspect, if present) but there was no certainty that the lawyer would speak the same language as the victim. There was no indication that interpreters were provided for the purpose of the police interview, and no recognisable system for addressing language diversity amongst witnesses, victims and suspects, despite provisions in the law for such measures being in place (see above).

All of the agencies reported the use of community judges in court as interpreters for nonPortuguese speaking witnesses. This is consistent with Mabasso (2013), who reports that senior judges tend to avoid the use of local languages, and that even when witnesses give evidence in their local language, senior judges continue to question them in Portuguese. Thus, community judges provide a crucial intermediary in such multilingual circumstances. The Commander of the Special Police Unit also referred to the use of lawyers as ad hoc interpreters in court and in the police station. These lawyers are generally from the same civil society organisations that took part in our study, and as mentioned above, proficiency in a local language was less common in that cohort. In fact, there was a notable lack of concern about the client's understanding of proceedings from a lawyer participant at AMMCJ, who simply stated the victims he represented in court "did not need to understand the judge" because he would explain to them what they needed to know about the judge's decision.

This contrasted with the findings from the Judicial Training College Director's interview, where it was made clear that there were specific legally binding provisions for court interpreters. This response is consistent with the Civil Process Code in its 2010 revised version (see Appendix A), which states that for those who do not speak Portuguese "a sworn interpreter is appointed to ensure communication" (Article 139, Section 2) and notes that "[t]he use of interpreters is necessary not only when foreigners are involved, but also with Mozambicans who speak languages other than Portuguese" (Issá et al. 2010, 89; see Appendix A for original Portuguese version).

However, the Director of the Judicial Training College, after noting the official position and legal requirements of the courts, went on to describe the needs for judicial officers to be 
trained to recognise the obstacles to justice caused by language diversity in Maputo and elsewhere in Mozambique. For example, the director was clearly concerned about the quality of the interpreting service provided, and emphasised several times during the interview the need for court interpreters to be trained in legal terminology and procedures, and hired on a permanent basis by the courts. She noted that the mistranslation of legal terminology was common because court interpreters were not adequately trained. She reported that in many instances, judicial officers would have to intervene to clarify the meaning of legal terms for the interpreters. She recognised that not all languages spoken in Mozambique were covered by the interpreter service, and that at times, when an interpreter was not available, the judicial officer would decide not to adjourn the case to await the arrival of the interpreter, but would press on with the case regardless, in order to save time and money. At times, legal officials were used as interpreters, which had the advantage that they understood the legal terminology and procedures. Nonetheless, as the director pointed out, the challenges would remain the same, given their limited knowledge of the corresponding terminology either in English or the local language. Translation in a legal setting is a very challenging task even for qualified professionals, and, overall, community judges have very basic or limited proficiency in Portuguese. Thus, when a qualified translator is not available in court, it is legal officers such as court bailiffs who are more likely to play the role of interpreter and this risks the integrity of the translation, given that they are not qualified.

When DV cases are taken to the community leadership, the case is dealt with according to customary law principles. Our Community Police informant was the founder of the first community policing unit in Mozambique and he pointed out that the community police officers' major concern is to attempt a more family-based solution for the case. As in most suburbs and rural areas, the use of a local African language is viewed as a way to allow victims to tell their story without facing the barriers associated with using the official language. When the case needs to be referred to a police station, it needs to be reported in Portuguese, and this entails a risk of creating two versions of the story.

\subsection{Resources Used to Respond to Linguistic Diversity}

In this section, we describe the use of material resources used to respond to linguistic diversity. As discussed above, responses using human resources included drawing on the staff members' own language knowledge in an interview or court trial, or the use of ad hoc interpreters, such as colleagues, family members and other available community members. 
In the civil society organisations, the most common resources used to respond to linguistic diversity were printed materials. These draw on multilingual education and information resources that are produced mainly in simple Portuguese but also in some local languages. Cartoons and posters were also popular means of communicating messages about civil rights and legal responsibilities, such as the illustrated booklets produced by the Liga, which used lots of pictures and simple Portuguese to convey information. Forum Mulher described short films made to explain legal rights and responsibilities about various issues relevant to Mozambican women; however, these were only produced in Portuguese. The participant from AMMCJ described radio and television public service announcements that were intended to inform the population about their rights, but assessed these as being too legalistic, and did not indicate that any were made in languages other than Portuguese.

Another popular means of communicating rights are education forums and public seminars. These are run by Muleide, for example, and the Centre for Human Rights, though again, it was not clear that there was a special effort made to present information in languages other than Portuguese.

In the Special Police Unit, the legal explanation provided to attendees by lawyers is accompanied by reference to Portuguese information brochures. Other government agencies did not specifically describe resources that they used, but interviews with the NGOs indicated that there are reasonably high quantities of Portuguese language materials produced but little in the way of local language translations.

In summary, the civil society organisations produced a range of printed and multimedia materials to assist victim-survivors of $\mathrm{DV}$, but few of our participants were aware of materials produced in languages other than Portuguese. Our interviews appeared to identify a gap between the acknowledged need for multilingual materials and the actual policies and initiatives required to produce them. In the following section, we explore this gap further and suggest practical steps that might begin to address the gap.

\section{Discussion}

The analysis of the data in the previous section provides a nuanced perspective from stakeholders on linguistic diversity amongst their clientele and how this affects justice 
outcomes in DV cases. This builds on prior research and country reports by donor organisations in several important ways. While census data can describe linguistic diversity and language distribution, for instance, it cannot provide any insights into the impact of language diversity on the daily lives of speakers. And whereas a country report can identify corrupt practices and institutional failure in the justice system, it does not investigate the experience of those practices or failures by the officers attempting to administer justice under such difficult circumstances. The interview data presented here addresses these gaps in the available research by investigating the intersection between language and the law at the point of contact between agencies and citizens.

Existing data and prior research indicate that the experiences of the stakeholders in this study are somewhat predictable. All of the stakeholders across the ten agencies reported high levels of linguistic diversity amongst their clientele, and low levels of proficiency in Portuguese. Despite the evidence that this is not a new or unexpected situation, the analysis suggests that there is an apparent reluctance by agencies to respond appropriately to the linguistic diversity of DV victims. This will be discussed here in relation to three factors that emerged from our data: the role of interpreters in the justice system; the attitude towards the victim's legal knowledge; and the linguistic features of the relevant languages themselves.

Firstly, it is clear that the response of these ten agencies to linguistic diversity amongst their clientele is highly dependent on the resources available to them. There seems to be an inverse relationship between the distance from the courtroom and use of interpreters by justice stakeholders. In the courtroom itself, there is an explicit acknowledgement of some need for interpreters, which is codified in the relevant legislation. Although the lack of resources, or prioritisation, means that interpreters are inadequately trained and not always unavailable, there is nonetheless some institutional support for the use of professional court interpreters. Even here, though, ad hoc interpreters (judges, lawyers and court officials) are drafted into service as required, and are even preferred because they are available and have appropriate legal knowledge.

Prosecutors reported the use of colleagues as ad hoc interpreters, as well as their own attempts to acquire a local language to better communicate with non-Portuguese speaking citizens, and there was a clear acknowledgement of the need for language services in their work. 
Police participants in the study, consistent with prior research (Mabasso 2013), did not report any use of interpreters, although they made frequent reference to the use of lawyers to explain legal terminology and to the availability of Portuguese language pamphlets. Thus, police participants reported a general recognition of linguistic diversity amongst DV victims but unlike in the courts, where some attempt is made to provide interpretation for nonPortuguese speaking citizens, there was no evidence of a formal police response to address the language barrier at the policy or institutional level.

Although civil society organisations are outside the formal legal system, they are still able to play an important role in providing legal assistance in court, and this can include language assistance. However, as indicated by the data analysis, the professional lawyers engaged by civil society organisations are least likely of all staff members to speak a language other than Portuguese, and so this is unlikely to adequately address the language needs of victims in court.

Community police officers were perhaps least likely to require an interpreter, as they conducted their work directly with the victims in their local language, and their statements did not seem to form part of the evidence chain.

Although language diversity was recognised as a barrier to communication by most stakeholders, it was rarely identified as causing a miscarriage of justice. At no point in the legal process, for instance, was the inadequacy of the interpreter service or the victim's lack of Portuguese proficiency described as constituting a breach of her rights or as being an obstacle to the administration of justice. This response was surprising, given the widespread recognition of the problem of low Portuguese proficiency, but is perhaps explained by reference to the second factor that was identified in the data analysis: the attitude of stakeholders towards the victim's legal knowledge.

The data point to a division in attitudes that seems to fall roughly along institutional, but also gender, lines. For instance, stakeholders within formal justice institutions, such as the judicial college, the PGR and the police, were clear that their clientele were frequently unable to speak or understand the Portuguese of the legal system. However they rarely expressed any concern that this might lead to a miscarriage of justice. Prosecutors at the PGR and officers at 
ACIPOL did note that there were advantages to women telling their story of abuse in their first language, and these observations were broadly consistent with the principles of therapeutic jurisprudence, which seek to address participants' therapeutic needs in their interactions with the justice system. Nonetheless, the concern for the victim's well-being displayed by our interviewees did not translate into a concern for her need to understand how the law applied to her case.

Civil society participants were more divided on this issue, which is surprising. That is, it was surprising that they did not universally support the victim's need for legal knowledge of her case, since civil rights education programmes are a mainstay of their work. In fact, there was a clear gender division amongst civil society participants, such that female participants were strongly supportive of a woman's need for legal knowledge about her case, whereas the male participants' response to the issue is summed up by the lawyer who stated that "she doesn't need to understand the judge" and went on to explain that he would tell her what she needed to know about the court case.

While it is perhaps fair to say that such patronising attitudes of legal professionals towards their clients can be found in any society, this attitude is especially concerning amongst lawyers in Maputo, where women experiencing DV are already so severely disadvantaged. The lack of interpreter services throughout the justice system in Maputo means that many victims of DV are reliant on ad hoc interpretation from lawyers and advocates. Rather than responding to this situation with concern, as demonstrated by the female civil society participants, or activism, as demonstrated in neighbouring South Africa (Ralarala 2014), these male lawyers respond by asserting their professional right to act as gatekeepers to justice.

The third factor that appears to have restricted the quality and availability of legal interpreters is the technical challenge posed by the linguistic task of interpreting between Portuguese and the Bantu languages spoken in Maputo. Stakeholders from the PGR, police and the judicial college were emphatic that interpreters needed to be better trained to understand the legal implications of the terminology used in legal proceedings, and much of the civil society organisations' work was in providing plain language (Portuguese) descriptions of legal rights and processes. Thus a common theme in the interview data was the difficulty of translating the terminology of the formal Portuguese written legal code into local Mozambican 
languages. However, a theoretical linguistic perspective on this issue immediately reveals that this is not a problem that can easily be overcome with better-trained legal interpreters, although that is certainly a requirement of the Mozambican justice system in any case. Rather, the problem lies in the lack of suitable lexemes in Bantu languages that can be used to translate the specific and technical terminology of legal Portuguese. While it might be possible to offer a translation into a Mozambican (Bantu) language using legal terms drawn from customary court practices, these do not convey the specific legal implications of a term or phrase used in the context of the formal written code of law. Without a suitable translation to convey the legal implications of specific terms, even the most fluent and professional interpreter will be very hard-pressed indeed to provide an adequate explanation of police and court processes, and non-Portuguese speaking victims are indeed left only with what the lawyers decide "she needs to understand."

\section{Concluding Remarks and Recommendations}

This study of attitudes and beliefs about linguistic diversity in the Mozambican justice system has revealed several areas that might be addressed through innovative projects and changes in practices. Firstly, the need for interpreters needs to be taken seriously. There are interpreting schools and tertiary departments in Maputo, but the emphasis is placed on training interpreters to work between Portuguese and non-Mozambican languages, and not between Portuguese and local Bantu languages. There are clear financial reasons why this is the case - foreign visitors and businesses are prepared to pay more for language services than the cash-strapped local justice institutions - but this can be addressed through donor funding being directed towards training that includes Bantu language interpretation alongside training for interpreters in non-Mozambican languages.

Beliefs about and attitudes towards a woman's right to understand the legal processes surrounding her DV case are more difficult to tackle, and to some extent lie outside the scope of this research. However, perhaps an alternative strategy is to continue the work of civil society organisations to empower women through education, despite the patronising attitude of some legal professionals working in the sector. Thus, it is vital to provide legal rights education in Bantu languages, or in pictorial formats, in order to bridge the gap between Portuguese-language legal system and Bantu-speaking victims of DV. This will mean finding a means by which to translate Portuguese legal terminology into Bantu languages without losing the legal meaning and implications. 
However, the problem of translation is by no means unique to Mozambique. In Australia, for instance, the same problem has been tackled by linguists working in the Northern Territory where English legal terminology needs to be made comprehensible to speakers of Aboriginal languages (Aboriginal Resource and Development Services 2015). The plain English definitions must be legally consistent with the original term, and this requires input and advice from lawyers and those specialising in the semiotics of law, as well as from linguists and Aboriginal interpreters.

Information resources, such as a plain Portuguese legal dictionary with Bantu language translations of the definitions, would complement the work of all the stakeholders we interviewed in this study. It seems likely that similar resources could be developed for neighbouring South Africa, where eleven languages are officially recognised and used in the justice system, only two of which, English and Afrikaans, include a fully developed legal terminology.

In closing, whilst acknowledging the serious and entrenched nature of DV in Maputo, we hope that we might facilitate the empowerment of victims through better access to the language of the law. When we interviewed the head of the Special Police Unit for Domestic Violence, who is a prominent commentator on DV issues in Mozambique, we observed a large corkboard on her wall filled with photos of women showing gross injuries they had sustained from DV attacks. At the close of the interview, she gestured towards the photos, explaining that "they inspire me to keep going." We are likewise inspired to continue to promote language equality and access to justice in Mozambique by the thoughtful dedication and perseverance of our participants.

\section{Acknowledgements}

This research was generously funded by the RMIT Foundation International Research Exchange Fellowship scheme and the Centre for Global Research. We are also deeply grateful to our interpreter, José Raphaél, and the participants at all the stakeholder organisations. 


\section{References}

Aboriginal Resource and Development Services. 2015. The Plain English Legal Dictionary. Accessed February 20, 2018. https://ards.com.au/resources/downloadable/legaldictionary-plain-english-to-djambarrpuyngu/

Arthur, M. J., and M. Mejia. 2007. Rebuilding Lives: The Strategies of Women Survivors of Domestic Violence. Maputo: WLSA.

Brown J. 2011. "We Mind and We Care but Have Things Changed? Assessment of Progress in Reporting, Investigating and Prosecution of Rape." Journal of Sexual Aggression 17 (3): 263-272.

Cotterill, J. 2003. Language and Power in Court: A Linguistic Analysis of the O. J. Simpson Trial. London: Palgrave Macmillan.

Ehrlich, S. 2001. Representing Rape: Language and Sexual Consent. London: Psychology Press.

www.genderindex.org (accessed March 25 $5^{\text {th }}, 2018$ )

Gibbons, J. 2003. Forensic Linguistics: An Introduction to Language in the Justice System. Oxford: Blackwell Publishing.

Government of Mozambique 2005. Balanço do PES 2005. Maputo: Government of Mozambique.

Hertog, E., and J. van Gucht, eds. 2008. Status Quaestionis: Questionnaire on the Provision of Legal Interpreting and Translation in the EU. Antwerp: Intersentia.

Heydon, G., and A. Powell. 2016. "Written-Response Interview Protocols: An Innovative Approach to Confidential Reporting and Victim Interviewing in Sexual Assault Investigations." Policing and Society. https://doi.org/10.1080/10439463.2016.1187146.

Instituto Nacional de Estatística, Ministerio da Saude, M, Moçambique, and MEASURE DHS/ICF International 2012, Moçambique, inquérito demográfico e de saúde 2011, Maputo, Mozambique: Instituto Nacional de Estatistica.

Issá, A. C. M., I. Garcia, N. Jeque, and T. Timbane. 2010. Código de Processo Penal (com as Alterações Introduzidas). Maputo: UTREL - Unidade Técnica de Reforma Legal. 
Jetha, E., Lynch, C., Houry, D., Rodrigues, M., Baltazar, C. and Sasser, S. 2011. "Characteristics of Victims of Family Violence Seeking Care at Health Centers in Maputo, Mozambique.” Journal of Emergencies, Trauma, and Shock 4 (3): 369-377.

Kamwangamalu, N. 2016. Language Policy and Economics: The Language Question in Africa. London: Palgrave Macmillan.

Loforte, A. M. 2009. "Social Movements and Violence against Women in Mozambique: Landmarks on a Journey", Outras Vozes, vol. 28. Accessed January 8, 2015. http://www.wlsa.org.mz/article-social-movements-and-violence-against-women-inmozambique-landmarks-on-a-journey/.

Lopes, A. J. (1998) "The Language Situation in Mozambique", Journal of Multilingual and Multicultural Development, 19:5, 440-486, DOI: 10.1080/01434639808666364

Mabasso, E. 2013. "Official Language, Written and Customary Laws in Mozambican Police Stations" Paper presented to the 11th Biennial Conference of the Association of Forensic Linguists/Language and the Law (IAFL), Universidad Autonoma de Mexico, June 24-27, 2013.

Matoesian, G. 1993. Reproducing Rape: Domination through Talk in the Courtroom. Chicago: University of Chicago Press.

Open Society Initiative for Southern Africa. 2006. Mozambique: Justice Sector and the Rule of Law. Open Society Initiative for Southern Africa, London and South Africa Accessed March 25 $5^{\text {th }} \quad 2018$. http://www.unicef.org.mz/cpd/references/21Mozambique\%20Justice\%20report\%20(Eng).pdf.

Pathfinder International. 2015. Multisectoral responses to gender-based violence in Mozambique, Watertow, MA: Pathfinder International.

Pimentel, D. 2011. "Legal Pluralism in Post-Colonial Africa: Linking Statutory and Customary Adjudication in Mozambique." Yale Human Rights and Development Law Journal 14: 59-104.

Ralarala, M. 2014. “Transpreters' Translations of Complainants' Narratives as Evidence: Whose Version Goes to Court?" The Translator 20 (3): 377-395. https://doi.org/10.1080/13556509.2014.934002.

Robinson, C. D. 1993. "Where Linguistic Minorities Are in the Majority: Language Dynamics amidst High Linguistic Diversity." AILA Review 10: 52-70. 
Saini, F., E. Cumbe, and M. Levy. 2013. Post-Rape Care for Children in Mozambique: Assessment Report. Arlington, VA: USAID's AIDS Support and Technical Assistance Resources, AIDSTAR-One, Task Order 1.

Trinch, S. 2003. Latinas' Narratives of Domestic Abuse: Discrepant Versions of Violence. Amsterdam: John Benjamins.

United States Department of State. 2012. Country Reports on Human Rights Practices for 2012: Mozambique Human Rights report. Washington, D.C.: Bureau of Democracy, Human Rights and Labor.

Zacarias, A. E., G. Macassa, L. Svanstrom, J. J. F. Soares, and D. Antail. 2012. "Intimate Partner Violence against Women in Maputo City, Mozambique." BMC International Health and Human Rights 12 (35). https://doi.org/10.1186/1472-698X-12-35.

\section{Appendix A Original Version Civil Process Code (extract)}

(Línguas Nacionais)

O Estado valoriza as línguas nacionais como património cultural e educacional e promove o desenvolvimento e utilização crescente como línguas veiculares da nossa identidade. (Constituição da República, 2004:7)

Artigo 10

(Língua Oficial)

Na República de Moçambique a língua portuguesa é a língua oficial. (Constituição da República 2004, 7)

Artigo $139 .^{\circ}$

(Língua a empregar nos actos)

1. Nos actos judiciais usa-se a língua portuguesa.

2. Aqueles que hajam de ser ouvidos podem, no entanto, exprimir-se em língua diferente, se não conhecem a língua portuguesa, devendo nomear-se um intérprete, quando seja necessário, para, sob juramento de fidelidade, estabelecer a comunicação. $(*)$

Anotação

* Consagra-se a necessidade do intérprete não só quando se está perante estrangeiros, mas mesmo quando se trate de nacionais que não falem a língua portuguesa. (Issa et al. 2010, 89)

\section{Appendix B Interview Schedules}

Agencies: Civil society agencies

Police interviews and victims experience 
- How do victims respond to being interviewed by police?

- What are their expectations about the outcome of the police interview?

- Is there a knowledge gap for victims about the legal pathway for making a complaint?

- Could multilingual materials address this gap?

- If so, in what format?

- And with what content?

- Who would be best to produce them? (eg, cooperative arrangement between the Liga, UEM...others?)

- What is already available?

Statement taking for victim support agencies - training and practices

- What training do staff get now?

- Are staff trained in interviewing techniques?

- Would it be helpful to have interviewing aids (prompts, apps in various languages?)

\section{Agency: ACIPOL}

Training for the police in interviewing witnesses

- What training is presently undertaken in interviewing?

- What are the main goals of the training?

- What is the role of evidence in police interviewing?

- How does police interview evidence get presented in court cases?

- Is it satisfactory?

- How does the current system of police interviewing and evidence deal with the multilingual context of Maputo?

\section{Agencies: PGR and Judicial Training College}

- What is the role of evidence in police interviewing? 
- How does police interview evidence get presented in court cases?

- Is it satisfactory?

- How does the current system of police interviewing and evidence deal with the multilingual context of Maputo?

- How does the customary law process impact on victims' experiences in the formal legal system?

- How do victims respond to being interviewed by police?

- What are their expectations about the outcome of the police interview?

- Is there a knowledge gap for victims/perps about the legal pathway for making a complaint?

- Could multilingual materials address this gap?

- What is already available?

\section{Agency: Special Police Unit (gabinete)}

Training for the police in interviewing witnesses

- What training is presently undertaken in interviewing?

- What are the main goals of the training?

- What is the role of evidence in police interviewing?

- How does police interview evidence get presented in court cases?

- Is it satisfactory?

- How does the current system of police interviewing and evidence deal with the multilingual context of Maputo?

Police interviews and victims experience

- How does the customary law process impact on victims' experiences in the formal legal system?

- How do victims respond to being interviewed by police? 
- What are their expectations about the outcome of the police interview?

- Is there a knowledge gap for victims/perps about the legal pathway for making a complaint?

- Could multilingual materials address this gap?

- If so, in what format?

- And with what content?

- Who would be best to produce them? (eg, cooperative arrangement between LIGA, UEM...others?)

- What is already available?

Statement taking for victim support agencies - training and practices

- What training do staff get now?

- Are staff trained in interviewing techniques?

- Would it be helpful to have interviewing aids (prompts, apps in various languages?) 